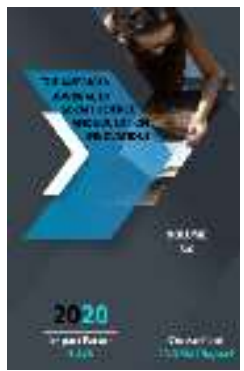

Journal Website: http://usajournalshub.c om/index,php/tajssei

Copyright: Original content from this work may be used under the terms of the creative commons attributes 4.0 licence.

\section{Methodology Of The Folk Stage Dance Of The Honored Artist Of Uzbekistan And Karakalpakistan Taymuraz Muratovich Tekoev}

Raisa (Rano) Dosmetova

Senior Lecturer At The State Conservatory Of Uzbekistan, Uzbekistan

\title{
ABSTRACT
}

An analysis of the teaching methods of various subjects makes it possible to anticipate and manage the pedagogical process of development of a future ballet dancer.

\section{KEYWORDS}

Folk stage dance, teacher, teaching methodology.

\section{INTRODUCTION}

Science describes pedagogical facts, phenomena, processes, explains by what laws, under what conditions, why in one way or another the processes of education and upbringing take place in one way or another. The result of research should be pedagogical systems, technologies, and educational processes designed to achieve a given result, i.e. an explanation of the phenomenon; the theory leads to the creation of pedagogical systems, methods, teaching technologies, educational tools, and textbooks.

M. Petipa, L. Ivanov ("the Nutcracker" by P. Tchaikovsky, "Rhapsodies" By F. Liszt) and other ballet masters played a great role in the formation and development of folk stage dance. 
In the XX century, the ballets of Saint-Leon, $M$. Petipa, and L. Ivanov established a divertimental form of characteristic dance, which carries a dramatic load and creates an atmosphere of action. This enriched the ballet and its perception by audience.

\section{MATERIALS AND METHODS}

Further development of the characteristic dance is associated with the names of $M$. Fokin (1880-1942) and A. Gorsky (1871-1924). M. Glinka, A. Borodin, N. Rimsky-Korsakov, A. Dargomyzhsky and others gave the theater the development of musical folk themes for creating stage dance. However, in this case, the performances of characteristic dances lagged behind the music.

The first teacher of character dance in St. Petersburg ballet school was I. F. Kshesinskaya ("mazurist") (1823-1905). He demanded from the students not only the performance of movements, but also sought "chic" and "fire" in the manner of performance. A. F. Bekefi creates a scheme of a characteristic dance lesson: at the barre and in the middle. A. Shiryaev, A. Bocharov authors of the first textbook on folk stage dance. To this day, this scheme remains valid with minor changes, and this tutorial is one of the main ones.

In the ballets of R. Zakharov and other choreographers, the growth of national art took place.("Gayane", "Shurale", "Taras Bulba").Leaving the ballet of a characteristic dance exsanguinated and deprived it of its root system.

The world's leading choreographers and teachers regretted that folk-stage dance was leaving ballets and thus impoverishing them.

Taimuraz Muratovich Tekoev is no exception, and in his work he continued the best traditions of the Russian school, which he received from his teachers: I. V. Smirnov, ballet master People's Artist of Russia (a student of R. Zakharov) V. G. Kashtakov, soloist of the State Dance Ensemble named after I. A. Moiseev, M. I. Shlyapnikova -soloist of the State Dance Ensemble "Berezka" M. V. Smirnova, Ya.g. Sangovich, G. K. Farmanyantssoloists of The State Bolshoi Opera and Ballet Theater of Russia, A. A. Klimov -soloist Pyatnitsky State Russian Folk Choir.

The best traditions of folk-stage dance got its development in Taimuraz Muratovich's teaching methodology .

What are the features of conducting a lesson by T. M. Tekoev?First of all, these are the basic truths of pedagogy: discipline, responsibility, and honesty. (Start the lesson on time; it was not late or missed, neat clothing, full attention.).He achieved this, as they say, by the way of the carrot and stick. He was very strict, but at the same time, always fair, to each individual approach. He knew how to touch the strings of the soul, which later allowed students to reveal the best sides of their capabilities. He never kicked out of the class for any misconduct and did not leave the class angry. The peculiarity of his work is selfdiscipline: he carefully prepared for the lesson, was not late, changed his clothes, was eager to work, wanted to deliver what was planned as soon as possible. Staging work was always complex and meticulous, accompanied by explanations and demonstration of movements. The cult of the teacher reined in the class. As I. A. Moiseev said, in choreography it is impossible without it (in a good sense of the word). The ability to create an atmosphere of work and creativity, at the same time unquestioning obedience and conscious process, is worthy of special discussion. It is difficult even to analyze how this was achieved. Probably everything - the teacher's attitude to the lesson, his respect for the students, his contact with the concertmaster. Great 
attention he paid attention to the musical accompaniment of the lesson, and there were no voids during the lessons. He could switch the students ' attention by telling stories, thereby giving them the opportunity to rest. "A pause is a study," repeated N. I. Tarasov. This was how the work was switched from muscles to thinking, understanding the movement, analyzing what was done, mistakes, and ways to overcome them. As his students say, the reward for hard work was his reciprocal look that spoke of satisfaction. This is not even verbal praise, but a kind look. Sweaty, tired and grateful students, a satisfied teacher, leaving the class, were happy. For this, he is loved by all those who studied with him.

Also surprisingly important in his teaching method is "difficult children". He could see their strengths and reveal them in the classroom. He had never complained about the students, he understood everything and often encouraged many with good grades. Sometimes there was a continuation-meetings and conversations at home. As one of the great teachers said: "A teacher is not someone who considers himself to be a teacher, but the one whom the students consider their teacher."Among those are People's Artist of Russia D. Korsuntsev and others.

\section{RESULT AND DISCUSSION}

The problem of educating a real dancer in a ballet school is a huge scrupulous work of many teachers. Students begin to engage in a folk stage dance when they have mastered the basics of classical dance. And only then a folk dance is superimposed on this knowledge. The teacher has a big task - to make the student fall in love with this subject. It is very difficult for children to perform the technical part of movements and at the same time to express the character and manner of a particular people.
T. M. Tekoev taught folk stage dance at the State Higher School of Folk Dance and Choreography for 4 years. These were pregraduation and graduation classes. Having a good Russian choreographic education, he passed on his knowledge to his students, using not only his knowledge of dance, but also pedagogical methods of education. What was it? First of all, as in any business, he himself was very fond of folk dance. Previously working in the State Folk Dance Ensemble of North Ossetia "Alan", Tekoev T. M. experienced the whole school and therefore in the class there was always a good display of movements by the teacher. This is one of the most important factors in the conduct of classes, this is known to all specialists in this profession. Then, starting to study the dances of a particular nation, Taimuraz Muradovich talked a lot about these people, country and, on occasion, showed videos. Being a very musical person, he scrupulously and for a long time worked on the selection of musical material with an accompanist or a musical recording. Music should be liked and perceived by both the teacher and students.

The lessons were interesting and challenging. He was able to achieve filigree purity in the execution of movements and precise musicality. What is valuable is that this is not "training" as choreographers say, but a gradual entry into the movements and the material itself. He considered the characteristic exercise at the ballet barre necessary in the lower and middle classes. In high school, Tekoev, a master of his craft, improvised very interestingly and composed "master classes", where graduates performed exercises in the middle of the hall. These were various compositions, including on Russian material, where the ballet barre turned into exercises in the middle of the hall - these are fractions, rotations and tricks. The etudes composed by Timuraz Muratovich were always detailed and 
rich. He persistently sought the technique of execution and expression of the characteristics of the character of the people.

In his lessons there were samples of folk stage dance, and performances to music from famous ballets. So a successful mass number was set to music by V. Zhelobinsky- a Gypsy dance, although we all know that this production of a performance for three people from the ballet Don Quixote" by a ballet master Kasyan Goleizovsky. He was not afraid of these experiments, as he possessed an outstanding talent as a ballet master. One of the many final exams (there were more than sixty of them over the years), he prepared for the soundtrack. It was great! The orchestral sound made it even better for students to experience everything for real. This exam included "Gypsy tunes" by C. Saint-Saens," Spanish Capriccio " by Rimsky-Korsakov. Later, "Spanish Capriccio" was presented at the reporting concert of the State Higher School of National Dance and Choreography.

\section{CONCLUSION}

In general, this is a very demanding and loving teacher, and it was mutual. This kind of teaching of the subject was very successfully combined with classical dance, and as a result, when graduate came to the theater, such a ballet dancer was ready to perceive his roles in a ballet performance or to work in a dance ensemble.

Summing up T. M. Tekoev's teaching methodology, the following must be emphasized: unconditional talent for composing a dance, love for the work and students, musicality, good taste, knowledge of the subject, constant ability to grow in this specialty, extensive work experience, knowledge of pedagogy. It was no accident that he spoke proudly of himself: "I am a teacher»
Today, his students dance in many theaters around the world, many teach folk stage dance and try to continue T. M. Tekoev's traditions in their own teaching methods.

\section{REFERENCES}

1. N.I. Tarasov "Classical dance" publishing house Art M. 1971

2. Encyclopedia - "Russian ballet" publishing house "Consent" 1997 